\title{
SHARIA AUDIT PROBLEMS IN ZAKAT INSTITUTIONS: EVIDENCE FROM INDONESIA
}

\author{
Aisyah As-Salafiyah ${ }^{\mathrm{a}}$ \\ Aam Slamet Rusydiana ${ }^{b}$ \\ ${ }^{a, b}$ Sharia Economic Applied Research \& Training (SMART) Indonesia \\ Email: assalafiyahsmart@gmail.com ${ }^{\text {a }}$; aamsmart@gmail.comb
}

\section{ARTICLE HISTORY}

Received:

20 November 2020

Revised:

7 December 2020

Accepted:

8 December 2020

Online available:

11 December 2020

Keywords:

Delphi,

Sharia Audit,

Zakat Institution

*Correspondence:

Name:

Aisyah As-Salafiyah

Email:

assalafiyahsmart@gmail.com

\section{ABSTRACT}

This study aims to determine the opinions and recommendations from the experts regarding the problem of the audit system in zakat institutions in Indonesia to determine the priority of the most important variables to be fixed. This research was conducted in August 2020 using primary data obtained from interviews with experts consisting of academics, practitioners and regulators with a background in sharia economics. The data were analyzed by the Delphi method to find the main priority and agreed upon convergence by experts. The results showed that of the 15 variables of audit problems at zakat institutions in Indonesia, there are 13 variables with convergent-convergent consensus based on expert opinion and only 2 variables with divergent consensus. The 3 main priority problems of auditing in zakat institutions in Indonesia are (1) an Insufficient number of sharia auditors, (2) The absence of strong rules related to sharia auditing, (3) HR competence. This research can be used by readers to make improvements in the audit system of zakat institutions in Indonesia with priority according to the findings of this study. This research is the first research that comprehensively calculates the expert's assessment regarding audit problems in Indonesian zakat institutions using the Delphi method and its priority recommendations.

\section{INTRODUCTION}

Sharia audits have an important role in the development of Islamic institutions including zakat institutions. In its implementation, every Islamic institution is directed at contributing to the achievement of the goals of Islamic law/maqahasid as-sharia (Kasim et al., 2009). The development of the potential and management of Islamic institutions (zakat institutions) leads to the development of increased trust in the institution itself to maintain the sustainability of the institution (Sawandi et al., 2017). One way to increase public trust is to expand the benefits of sharia auditing to cover processes, programs/products, the environment and society (Sultan, 2007). 
The need for certainty in compliance with sharia has prompted the emergence of a new audit function, namely sharia auditing. In this case, sharia auditors play a crucial role in ensuring the accountability of financial statements and compliance with aspects of sharia (Yaacob \& Donglah, 2012). This need is the same as the spirit of the formation of zakat law no 23 of 2011, which includes: institutionalizing, accountability, integrated, professional, and trustworthy as well as usefulness and justice. This aspect is also a focus on developing sharia audits in zakat institutions.

Sharia internal audit is formed in Islamic financial institutions due to several differences between Islamic governance and conventional corporate governance in general (Tooranloo \& Azizi, 2018). These differences can lead to differences in features, required internal audits, such as orientation, scope objectives, disclosures and reports, auditor skills, to the required qualifications (Algabry, Alhabshi, Soualhi, \& Othman, 2020).

Regarding zakat institutions in Indonesia, as an institution that regulates Islamic social finance under the Baznas institution, the audit sector is still not perfect and is still being improved. To support this gradual improvement, it is necessary to know and prioritize which problems should be prioritized to find solutions. The ultimate goal is to produce better sharia audit quality in Indonesia's zakat institutions, so that compliance with Sharia is more secure than before.

Based on this background, the authors limit the research gap to be studied, namely only focusing on assessing the ranking and description of priority problems that occur in the process of developing and implementing sharia audits in zakat institutions. The sharia audit referred to in this case, is a sharia audit related to sharia compliance carried out by zakat institutions in Indonesia.

\section{LITERATURE REVIEW}

\section{Sharia Audit}

In Islamic economics, sharia auditing can be likened to hisbah, which is an institution under the authority of the state that aims to safeguard the public and ensure that all transactions that take place are in accordance with sharia guidelines (Abd Rahman et al., 2020). The effectiveness of Islamic internal audit is believed by some experts to help develop the performance of Islamic financial institutions, this is because financial reports indirectly reflect the quality of its internal sharia audit department (Spiegel et al., 2012). So that sharia internal audit is considered the backbone of a business's accounting because it is the part that records all transactions that take place (Khalid \& Masron, 2015).

According to Lahsasna et al. (2018) and Yaacob and Donglah (2012), the main objective of the sharia audit is all activities carried out. And of course, there are different concerns from traditional audits, according to Sultan (2007) that the scope of sharia audits includes the aspects of financial statements, operations, structures people as well as information technology. 
In International Auditing Standards (IAS), as research conducted by Khan (1985) contained in Lahsasna et al. (2018) that traditional auditing is deeply for capitalists and Western Worldview. Meanwhile, in the International Auditing and Assurance Standard Board (IAASB), it is in line with what was said that traditional auditing only focuses on shareholders' trust.

There are many differences between traditional auditing and sharia auditing. As in Shafii et al. (2014) that traditional audits cannot provide an analysis of the aspects of usury, gharar and maisir. But only focus and presentation on the financial aspects of an institution or better known as a financial statement audit. Meanwhile, Sharia audit can cover all aspects of the needs of institutional activities. So in principle, the sharia principle is in line with all the activities carried out in the institution.

One of the objectives of implementing sharia audits in zakat institutions is the creation of supervision and aims to ensure that zakat management institutions carry out activities of collecting, distributing and utilizing consumptive and productive zakat and the use of amil rights based on sharia principles (Kemenag, 2018). It is also a part of performance measurement and taking action to ensure the desired results and becomes a process or step in management activities (Ichsan, 2011).

Sharia auditors ensure that zakat management institutions have risk management related to sharia compliance to minimize the potential for fraudulent practices and other potential mistakes (Kemenag, 2018). In Lahsasna et al. (2018), it is explained that the evolution and development of attesting institutions have been started since the era of the modern Sultan Beyazid II. This institution, called Hisbah, is an independent institution that has a role in socio-economic, moral, and market supervision, as an institution that can provide preventive actions for monopoly activities, standardization of products, facilities for needs and handling of fraud (Islahi, 2010).

According to observations made by Kasim et al. (2009) regarding Islamic institutions in Malaysia illustrates that the implementation and implementation of sharia auditing are still very minimal in the absence of a sharia audit framework and require the development of a sharia audit framework. With the same theme, Yaacob and Donglah (2012) stated that the sharia audit framework cannot be developed properly and needs great attention.

As is well known, at least in building a framework four aspects need to be considered, namely line management, management reviews, external audit and internal audit. 


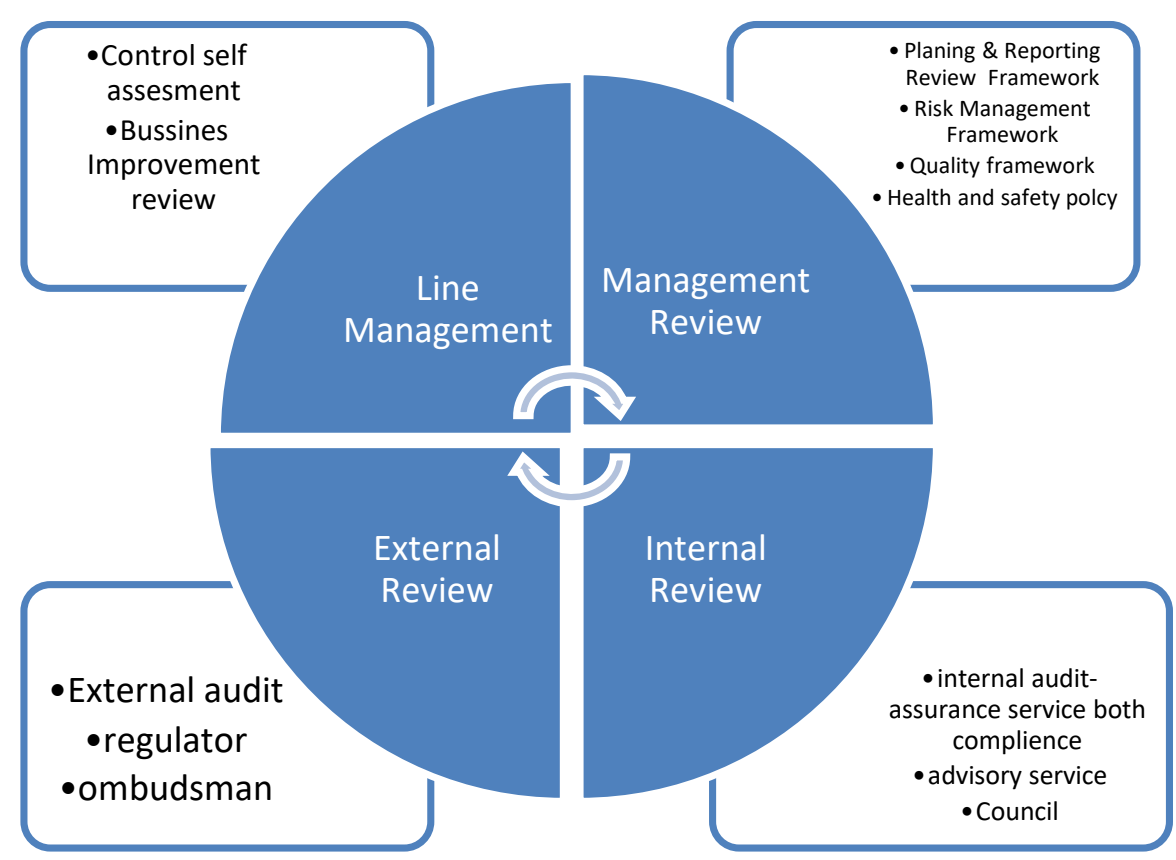

Figure 1. Audit and Assurance Framework

Islamic financial institutions, including zakat institutions in Indonesia, need to establish governance mechanisms, one of which consists of sharia audits, their existence is expected to reduce the level of non-compliance with sharia so that these institutions can run their business activities effectively without exposing their operational activities to unacceptable levels of risk. However, the task of reviewing the risk of non-compliance with sharia together with financial risk will spend more time on conducting sharia audits (Kaaroud et al., 2020).

Based on some of these previous studies, it was found that there have been many studies that discuss the problem of auditing in zakat institutions, both in the form of explanations of what sharia audits are, the urgency of zakat institutions in improving sharia audits, to how the implementation of the concept of sharia auditing in zakat institutions. However, not many studies discuss problems in sharia auditing in zakat institutions using the Delphi method, which involves experts from regulators and academics to practitioners. Therefore, this study seeks to evaluate the problems faced by zakat institutions that implement sharia audits with actual data in 2020 . This study also shows the priority order of problems so that zakat institutions can gradually improve them from the most important.

\section{Delphi}

According to Loë et al. (2016), the majority of research with the Delphi method uses a questionnaire with a Likert scale, ranking preferences, or a combination of scoring and reasons. In this study, the authors used a preference ranking approach with weights from 1 to 9 . The greater the weight value, the more important the variable according to respondents/expert panelists. 
The composition of expert respondents relates to the validity of the research results (Spencer-Cooke, 1989). Because in this method, the opinions and judgments of the panelists are taken and analyzed, it is very much determined by how the panel members are selected. (N. Dalkey \& Helmer, 1963)proved that statistically, the Delphi method has a tendency, not only to converge but also to converge in the right direction.

According to N. C. Dalkey (2018), the general characteristics of the Delphi method can be explained as follows: (1) Anonymous, meaning that in the use of questionnaires or other communication related to responses, identification of panelist members (experts) is stated anonymously or closed; (2) There is feedback control, meaning that the control allows interaction between panel members to reduce distortion. This interaction occurs at each stage where the previous results will be given at the next stage. Panelists were then asked to re-evaluate their initial assessment by comparing it with the group assessment; (3) Statistical group response, meaning that the group assessment is expressed as the statistical average of the panelist member's assessment.

N. Dalkey and Helmer (1963); Linstone and Turoff (2011); and Melander (2018) found that the main advantage of the Delphi method in groups is that the consensus will converge to reach an agreed assessment from the panelists. Applicationally, this method is very easy to use and does not require complex statistical or mathematical skills to design, implement, and analyze the Delphi method. This method also avoids the existence of groupthink, which shows the domination of one / two people in the group or better known as the bandwagon effect. The existence of flexibility is also a strength of this method if the panelists who may have limited time and location can have the opportunity to respond when they have spare time.

The limitation of the Delphi method is that the consensus generated from the Delphi method is not necessarily the true consensus, because it can be a false consensus. The pseudo consensus is not the best judgment, but rather a compromise position (Mitroff \& Turoff, 1973). According to Linstone and Turoff (2011), the weakness of this method is that it does not allow contributions from other perspectives related to problems in the model. Meanwhile, according to Barnes (1987), the assessment in the Delphi method is derived from groups that represent society and may not be representative.

The Delphi method is widely applied in various fields of research. Gupta and Clarke (1996) examined 463 Delphi related articles and concluded that the 3 most popular areas for Delphi application were education, business and healthcare. Other fields are related to manufacturing, management and IT, social science, real estate, engineering, transportation, the environment, even tourism.

So far, there are several types of Delphi method research, both standard and modified, including Delphi real-time spatial, Delphi group, Delphi market, Delphi realworld to Delphi policy. Based on a lot of literature in indexed and reputable journals, 
the majority of Delphi application research is conducted in 2 and 3 rounds. Meanwhile, the majority of participants or Delphi expert respondents were between 11 and 20 respondents.

\section{RESEARCH METHOD}

This research will use the Delphi method. According to Sossa et al. (2019), the 3 most widely used statistical indicators in the application of the Delphi method are the mean (average) value, the standard deviation value, and the interquartile range or IR value. Apart from these three statistical indicators, the other indicators are the median, cluster, mode and variance values. In this study, the statistical indicators used were the mean, standard deviation, and interquartile range values. This statistical indicator is used to see the level of convergence or consensus of experts. Consensus or opinion convergence is the final result of the Delphi method, to see the level of robustness of the existing variables.

According to Meijering et al. (2013), there are many indexes or measurement indicators to see the level of agreement or consensus among respondents, including DeMoivre index (DM), Strict agreement index (SA), Light's Kappa (KL), Fleiss' Kappa $(\mathrm{KF})$, Cronbach's alpha (CA), Inter-class correlation coefficient absolute (ICA) to Kendall's measure of concordance (W).

The Delphi method is a group process that involves interaction between the researcher and a group of experts related to a particular topic, and through the help of a questionnaire. This method is used to find common ground on future trends using a structured information gathering process. This method is useful when the opinions and judgments of experts and practitioners are needed in solving problems.

This study will use 3 statistical indicators that are most widely used in the application of the Delphi method, namely the mean (average) value, the standard deviation value, and the interquartile range or IR value. The first measure of convergence assessment is when the answers or ratings of all respondents have a standard deviation value of less than $1.5(<1.5)$. The standard deviation notation formula as it is known is as follows.

$$
S=\sqrt{\frac{\Sigma\left(x_{i}-\bar{x}\right)^{2}}{n-1}} \quad \text { or } \quad \sqrt{\frac{\Sigma x_{i}^{2}-\frac{\left(\Sigma x_{i}\right)^{2}}{n}}{n-1}}
$$

where $x=$ Respondent A's answer to instrument $\mathrm{n} ; \bar{x}=$ Mean respondents' answers to the instrument $n$.

The next measure of consensus or convergence assessment is when the answers or ratings of all respondents have an Interquartile Range (interquartile range) or IR value of less than $2.5(<2.5)$. The calculation of the IR value is the difference between the upper and lower quartiles $(I R=Q 3-Q 1)$, where the quartile value formula is as follows: 


$$
\begin{aligned}
& Q_{1}=\frac{x_{\left(\frac{n-1}{4}\right)}+x_{\left(\frac{n+3}{4}\right)} \ldots .}{2} \\
& Q_{2}=x_{\left(\frac{2(n+1)}{4}\right)} \cdots \ldots \ldots \ldots . . . . . \\
& Q_{3}=\frac{x_{\left(\frac{3 n+1}{4}\right)}+x_{\left(\frac{3 n+5}{4}\right)}}{2} .
\end{aligned}
$$

The measurement to express the convergence or level of consensus on all variables is when the standard deviation value $<1.5$ and the value of the interquartile range $<2.5$. If one of the indicators does not meet the requirements, then the variable is declared not convergent or not agreed (divergent). Meanwhile, for variables that have reached the requirements, the next step is to rank with the highest average value for each variable that reaches consensus (convergent).

\section{RESULT AND ANALYSIS}

There are 15 sharia audit problems in zakat institutions in Indonesia based on the reference literature, namely the following: (1) The absence of strong rules, (2) Authorization issues, (3) Budget policy, (4) Scope of sharia auditing, (5) Islamic audit fiqh indicators, (6) Sharia audit framework, (7) Lack of sharia auditors, (8) HR competence, (9) Sharia auditor qualification standards, (10) Sharia audit SOP \& techniques, (11) Compliance monitoring standards, (12) Determination of tested indicators, (13) Lack of universities that focus on sharia auditing, (14) Lack of sharia audit literature and (15) Lack of sharia audit experts.

Of all the elements of sharia audit problems at zakat institutions in Indonesia, the following is a complete table showing the results of the weight given by 11 expert respondents consisting of academics, practitioners and regulators.

Table 1

\begin{tabular}{|c|c|c|c|c|c|c|c|c|c|c|c|}
\hline There are no strong rules yet & 8 & 9 & 8 & 8 & 6 & 6 & 8 & 7 & 8 & 8 & 8 \\
\hline Authorization Problem & 8 & 8 & 7 & 7 & 6 & 7 & 7 & 7 & 7 & 7 & 7 \\
\hline Budget policy & 7 & 7 & 6 & 6 & 6 & 6 & 6 & 6 & 7 & 8 & 6 \\
\hline Sharia audit scope & 8 & 7 & 7 & 8 & 6 & 6 & 7 & 7 & 8 & 9 & 7 \\
\hline Fiqh of sharia audit indicators & 7 & 6 & 6 & 7 & 6 & 5 & 7 & 8 & 8 & 9 & 3 \\
\hline Sharia audit framework & 8 & 7 & 5 & 7 & 7 & 6 & 7 & 8 & 7 & 9 & 7 \\
\hline Lack of sharia auditors & 8 & 7 & 9 & 8 & 6 & 7 & 8 & 8 & 8 & 8 & 8 \\
\hline HR competencies & 8 & 7 & 7 & 8 & 7 & 6 & 8 & 8 & 8 & 8 & 7 \\
\hline $\begin{array}{l}\text { Sharia auditors qualification } \\
\text { standards }\end{array}$ & 8 & 8 & 6 & 6 & 7 & 6 & 8 & 8 & 8 & 7 & 7 \\
\hline SOP \& sharia audit techniques & 6 & 8 & 8 & 7 & 7 & 8 & 7 & 7 & 7 & 7 & 7 \\
\hline
\end{tabular}

Results of Expert Respondents' Answers

$\begin{array}{lllllllllllll}\text { SHARIA AUDIT PROBLEMS } & \text { R1 } & \text { R2 } & \text { R3 } & \text { R4 } & \text { R5 } & \text { R6 } & \text { R7 } & \text { R8 } & \text { R9 } & \text { R10 } & \text { R11 }\end{array}$ 


\begin{tabular}{|c|c|c|c|c|c|c|c|c|c|c|c|}
\hline $\begin{array}{l}\text { Compliance monitoring } \\
\text { standards }\end{array}$ & 7 & 7 & 7 & 6 & 7 & 7 & 8 & 6 & 7 & 7 & 8 \\
\hline $\begin{array}{l}\text { Determination of the indicators } \\
\text { tested }\end{array}$ & 7 & 7 & 8 & 8 & 7 & 6 & 7 & 6 & 7 & 8 & 7 \\
\hline $\begin{array}{l}\text { Lack of institution that focuses on } \\
\text { Sharia Audit }\end{array}$ & 8 & 8 & 9 & 7 & 7 & 7 & 6 & 7 & 7 & 7 & 8 \\
\hline Lack of Sharia Audit literature & 9 & 6 & 8 & 6 & 6 & 7 & 6 & 6 & 9 & 3 & 5 \\
\hline Lack of sharia auditing experts & 8 & 6 & 7 & 6 & 7 & 7 & 7 & 6 & 8 & 7 & 7 \\
\hline
\end{tabular}

In the application of the Delphi method, 3 statistical indicators are most used, namely the mean (average) value, the standard deviation value, and the interquartile range or IR value. Based on the results of data processing that has been carried out, the calculation of priority problems in auditing zakat institutions in Indonesia is as shown in the following table.

Table 2

Delphi Calculation Results LAZ Audit Problem

\begin{tabular}{|c|c|c|c|c|c|c|c|c|c|}
\hline \multirow{2}{*}{ LAZ AUDIT PROBLEMS } & \multirow{2}{*}{ Q1 } & \multirow{2}{*}{ Q2 } & \multirow{2}{*}{ Q3 } & \multirow{2}{*}{ IR } & \multirow{2}{*}{ STDEV } & \multicolumn{2}{|c|}{ CONSENSUS } & \multirow{2}{*}{ MEAN } & \multirow{2}{*}{ RANK } \\
\hline & & & & & & $\mathbf{I R}$ & STDEV & & \\
\hline There are no strong rules yet & 7 & 8 & 8 & 1 & 0.881 & Convergent & Convergent & 7.636 & 2 \\
\hline Authorization Problem & 7 & 7 & 7 & 0 & 0.514 & Convergent & Convergent & 7.091 & 8 \\
\hline Budget policy & 6 & 6 & 7 & 1 & 0.656 & Convergent & Convergent & 6.455 & 14 \\
\hline Sharia audit scope & 7 & 7 & 8 & 1 & 0.862 & Convergent & Convergent & 7.273 & 5 \\
\hline Fiqh of sharia audit indicators & 6 & 7 & 8 & 2 & 1.559 & Convergent & Divergent & 6.545 & 13 \\
\hline Sharia audit framework & 7 & 7 & 8 & 1 & 0.996 & Convergent & Convergent & 7.091 & 8 \\
\hline Lack of sharia auditors & 7 & 8 & 8 & 1 & 0.75 & Convergent & Convergent & 7.727 & 1 \\
\hline HR competencies & 7 & 8 & 8 & 1 & 0.656 & Convergent & Convergent & 7.455 & 3 \\
\hline $\begin{array}{l}\text { Sharia auditors qualification } \\
\text { standards }\end{array}$ & 6 & 7 & 8 & 2 & 0.833 & Convergent & Convergent & 7.182 & 6 \\
\hline SOP \& sharia audit techniques & 7 & 7 & 8 & 1 & 0.575 & Convergent & Convergent & 7.182 & 6 \\
\hline $\begin{array}{l}\text { Compliance monitoring } \\
\text { standards }\end{array}$ & 7 & 7 & 7 & 0 & 0.603 & Convergent & Convergent & 7.000 & 11 \\
\hline $\begin{array}{l}\text { Determination of the } \\
\text { indicators tested }\end{array}$ & 7 & 7 & 8 & 1 & 0.668 & Convergent & Convergent & 7.091 & 8 \\
\hline $\begin{array}{l}\text { Lack of institutions that focus } \\
\text { on Sharia Audit }\end{array}$ & 7 & 7 & 8 & 1 & 0.771 & Convergent & Convergent & 7.364 & 4 \\
\hline Lack of Sharia Audit literature & 6 & 6 & 8 & 2 & 1.671 & Convergent & Divergent & 6.455 & 14 \\
\hline Lack of sharia auditing experts & 6 & 7 & 7 & 1 & 0.668 & Convergent & Convergent & 6.909 & 12 \\
\hline
\end{tabular}

Based on the table above, of the 15 variables of sharia audit problems in LAZ Indonesia, it is found that 13 variables have been approved by experts and only 2 variables have not been agreed upon. Two variables that were not agreed upon regarding the issue of sharia auditing at LAZ in Indonesia, namely the indicator of Islamic Fiqh for sharia auditing and the lack of Islamic audit literature.

While the order of the most important variables in the problem of sharia auditing in zakat institutions in Indonesia is as follows: (1) Insufficient number of sharia auditors, (2) There is no strong rule regarding sharia auditing, (3) HR competence, (4) Lack of focus universities in sharia auditing, (5) Scope of sharia auditing, (6) sharia 
auditor qualification standards, (6) SOP \& sharia audit techniques, (8) Authorization issues, (8) Determination of tested indicators, (8) Sharia auditing framework, (11) Compliance monitoring standards, (12) Lack of sharia audit experts, and (13) Budget policy.

\section{Analysis}

Based on the Delphi results above, the results show that the first priority of the most important variable in the problem of sharia auditing of zakat institutions in Indonesia is the lack of the number of sharia auditors, this is indicated by an average value of 7.72 and a convergent consensus. At present, the development of the number of zakat institutions including Islamic financial institutions in Indonesia has not been matched by the number of sharia auditors, so that the lack of the number of sharia auditors is a major problem priority in sharia auditing according to experts (Algabry, Alhabshi, Soualhi, \& Alaeddin, 2020).

The number of auditors who are competent in sharia matters can still be small in some countries, one of which is the LAZ in Indonesia (Khan, 2003), so it is found that the same sharia auditors work in several LAZs at the same time, although there are positive impacts, for example, the formation of a consistent and common standard among several LAZ in all services and products offered by LAZ, so that AAOIFI sees the need to overcome these challenges by providing quality training for Certified Shari'a Adviser and Auditor (CSAA) and Certified Islamic Professional Accountant (CIPA) (Rashidah \& Faisal, 2015). Therefore, the limited number of sharia auditors is one of the main factors affecting the effectiveness of sharia audits (Khalid \& Masron, 2015).

Furthermore, the variable of the problem of sharia auditing in zakat institutions in Indonesia occupies the second priority, namely the lack of strong rules regarding sharia auditing, this variable has a value of 7.63 and a convergent consensus based on the opinions of experts. Among the reasons is, the regulatory conditions and accounting practices in several Islamic countries, as well as post-colonial countries, still depend on Western trends (Kamla \& Haque, 2019).

The problem is that there is still a lack of strong rules related to sharia auditing, which is also supported by the recommendation to revise the provisions of the Internal Shariah Review (ISR) which are considered not in accordance with the independence and qualifications of sharia internal auditors (Sulub et al., 2020). Because LAZ operates under government supervision, which means that they are regulated by regulations set by the government, the expertise of sharia auditors is different from ordinary companies because they have to follow applicable regulations (Kaaroud et al., 2020). Currently, existing regulations related to sharia audit regulations are issued by the ministry of religion, namely KMA (Minister of Religion Decree) number 733 of 2018 which provides assistance related to sharia audits in zakat institutions, so it is interesting to note the extent to which the effectiveness of this KMA application is. 
respondents stated that the lack of regulation is a major problem in zakat inspection agencies in Indonesia.

The third priority problem of sharia auditing in zakat institutions in Indonesia is the competence of human resources with an average score of 7.45 and a convergent consensus based on expert opinion. This is a challenge for all individual financial managers, especially in the field of sharia auditing (Johari \& Sayed Hussin, 2016). Although the competence of each individual can be assessed by, for example, looking at the educational background of accounting or experience in conducting financial analysis, HR competence can still be improved by providing education, training and experience that is relevant and adequate for sharia auditors.

Competence and capability of human resources, especially sharia auditors, are considered to be one of the most important pillars in improving the internal control system in improving the quality of audit results. This is because the placement of competent human resources in accordance with sharia audit responsibilities can ensure their independence (Algabry, Alhabshi, Soualhi, \& Othman, 2020). The better the HR competency, the more professional the qualifications, as well as in the context of sharia auditing, the competence of auditors has an impact on adherence to rules and standards derived from the sharia framework, namely regulating economic transactions (Rashidah \& Faisal, 2015).

Besides, the competencies that must be met by a sharia auditor according to AAOIFI standard No. 3 Paragraph 12 is that internal auditors must have the disciplines and skills for the implementation of sharia internal audits. Ability and understanding of the rules and principles of Islamic Sharia in general, and Fiqh Muamalat in particular, are required in conducting internal Sharia audits. Therefore, in addition to having audit skills, internal auditors must also have additional qualifications in the form of sharia knowledge (Khalid \& Masron, 2015).

\section{CONCLUSION}

Based on the Delphi analysis results from the assessment given by experts consisting of practitioners, academics, and regulators, there are 15 variables of sharia audit problems at LAZ in Indonesia, of which 13 variables have been approved and only 2 variables have not agreed upon. From the calculation results, the three main priority issues for auditing zakat institutions in Indonesia are as follows: (1) Inadequate number of sharia auditors, (2) Lack of strict rules regarding sharia auditing, (3) HR competence. These results can then be used as a reference for authorized parties to formulate regulations and strategies to improve the quality of sharia audits in zakat institutions in Indonesia.

Suggestions for practitioners are the need to improve the quality of sharia auditors' resources in zakat institutions and provide thorough training for auditors to understand Sharia's concept better. Recommendations for regulators are the need for evaluation regarding the implementation of the existing sharia audit regulations and 
helping zakat institutions implement them according to applicable regulations. As for academics, it is to keep updating research information by increasing the number of respondents or developing this research with other methods such as ANP to produce more robust and more comprehensive data.

\section{REFERENCES}

Abd Rahman, N., Mastuki, N., Osman, M. R., \& Kasim, N. (2020). Islamic legal maxim for Shari'ah audit in Islamic bank. Journal of Islamic Accounting and Business Research, 11(2), 457-471. https://doi.org/10.1108/JIABR-11-2017-0170

Algabry, L., Alhabshi, S. M., Soualhi, Y., \& Alaeddin, O. (2020). Conceptual framework of internal Sharīah audit effectiveness factors in Islamic banks. ISRA International Journal of Islamic Finance, 12(2), 171-193. https://doi.org/10.1108/IJIF-09-2018-0097

Algabry, L., Alhabshi, S. M., Soualhi, Y., \& Othman, A. H. A. (2020). Assessing the effectiveness of internal Sharīah audit structure and its practices in Islamic financial institutions: a case study of Islamic banks in Yemen. Asian Journal of Accounting Research. https://doi.org/10.1108/ajar-04-2019-0025

Barnes, J. L. (1987). An international study of curricular organizers for the study of technology. Virginia Tech.

Dalkey, N. C. (2018). Delphi. In An Introduction to Technological Forecasting (pp. 2530). https://doi.org/10.4324/9781351106450-3

Dalkey, N., \& Helmer, O. (1963). An Experimental Application of the DELPHI Method to the Use of Experts. Management Science, 9(3), 458-467. https://doi.org/10.1287/mnsc.9.3.458

de Loë, R. C., Melnychuk, N., Murray, D., \& Plummer, R. (2016). Advancing the State of Policy Delphi Practice: A Systematic Review Evaluating Methodological Evolution, Innovation, and Opportunities. Technological Forecasting and Social $\begin{array}{lll}\text { Change, 104(March 2016), 78-88. } & \text { 10 }\end{array}$ https://doi.org/10.1016/j.techfore.2015.12.009

Gupta, U. G., \& Clarke, R. E. (1996). Theory and applications of the Delphi technique: A bibliography (1975-1994). Technological Forecasting and Social Change, 53(2), 185-211. https://doi.org/10.1016/s0040-1625(96)00094-7

Ichsan, M. S. (2011). Zakah Criteria for Performance Excellent (Pedoman Kriteria Zakat untuk Kinerja Unggul). FOZ Forum Zakat.

Islahi, A. A. (2010). The Economic Ideas of Shah Wali-Allah al-Dihlawi. American Journal of Islamic Social Sciences, 27(2), 69-95. https://doi.org/10.35632/ajiss.v27i2.361

Johari, R. J., \& Sayed Hussin, S. A. H. (2016). Enhancing management integrity through auditability concept: a literature review. Humanomics, 32(4), 516-524. https://doi.org/10.1108/H-09-2016-0069

Kaaroud, M. A., Mohd Ariffin, N., \& Ahmad, M. (2020). The extent of audit report lag and governance mechanisms: Evidence from Islamic banking institutions in Malaysia. Journal of Islamic Accounting and Business Research, 11(1), 70-89. https://doi.org/10.1108/JIABR-05-2017-0069

Kamla, R., \& Haque, F. (2019). Islamic accounting, neo-imperialism and identity staging: The Accounting and Auditing Organization for Islamic Financial Institutions. 
Critical Perspectives on Accounting, 63(September 2019), 102000. https://doi.org/10.1016/j.cpa.2017.06.001

Kasim, N., Ibrahim, S. H. M., \& Sulaiman, M. (2009). Shariah auditing in Islamic financial institutions : exploring the gap between the "Desired " and the "Actual." Global Economy \& Finance Journal, 2(2), 127-137. http://irep.iium.edu.my/13560/1/6[1].-Nawal_latest.pdf

Kemenag, D. Z. (2018). Petunjuk Teknis Pengawasan Pendampingan Audit syariah di Lembaga Zakat.

Khalid, A. A., \& Masron, H. H. H. T. A. (2015). Relationship between internal Shariah audit characteristics and its effectiveness. Humanomics, 31(3), 354-371. https://doi.org/10.1108/H-04-2014-0037

Khan, M. A. (1985). Role of the Auditor in an Islamic Economy. Journal of Research in Islamic Economics, 3(1), 31-41.

Khan, M. A. (2003). Zakah Accounting and Auditing: Principles, Rules and Experience in Pakistan. Islamic Economic Studies, 10(2), 29-43.

Lahsasna, A., Hassan, M. K., \& Ahmad, R. (2018). Introduction to Sukuk. In Forward Lease Sukuk in Islamic Capital Markets (pp. 1-9). https://doi.org/10.1007/9783-319-94262-9_1

Linstone, H. A., \& Turoff, M. (2011). Delphi: A brief look backward and forward. Technological Forecasting and Social Change, 78(9), 1712-1719. https://doi.org/10.1016/j.techfore.2010.09.011

Meijering, J. V., Kampen, J. K., \& Tobi, H. (2013). Quantifying the development of agreement among experts in Delphi studies. Technological Forecasting and Social Change, 80(8), 1607-1614. https://doi.org/10.1016/j.techfore.2013.01.003

Melander, L. (2018). Scenario development in transport studies: Methodological considerations and reflections on delphi studies. Futures, 96(February 2018), 68-78. https://doi.org/10.1016/j.futures.2017.11.007

Mitroff, I. I., \& Turoff, M. (1973). Technological forecasting and assessment: Science and/or mythology? Technological Forecasting and Social Change, 5(2), 113134. https://doi.org/10.1016/0040-1625(73)90027-9

Rashidah, A. R., \& Faisal, D. (2015). Conceptualizing the duties and roles of auditors in Islamic financial institutions: What makes them different? Humanomics, 31(3), 354-371. https://doi.org/10.1108/H-04-2014-0037

Sawandi, N., Abdul Aziz, N. M., \& Saad, R. A. J. (2017). Zakat accountability practices: Case study of zakat institution. International Journal of Economic Research, 14(16), 223-232.

Shafii, Z., Ali, N. A. M., \& Kasim, N. (2014). Shariah Audit in Islamic Banks: An Insight to the Future Shariah Auditor Labour Market in Malaysia. Procedia - Social and Behavioral Sciences, 145(August 2014), 158-172. https://doi.org/10.1016/j.sbspro.2014.06.023

Spencer-Cooke, B. (1989). Conditions of Participation in Rural, Non-Formal Education Programmes: A Delphi Study. Educational Media International, 26(2), 115-124. https://doi.org/10.1080/0952398890260211

Spiegel, M. van der, Fels-Klerx, H. J. van der, Sterrenburg, P., Ruth, S. M. van, ScholtensToma, I. M. J., \& Kok, E. J. (2012). Halal assurance in food supply chains: Verification of halal certificates using audits and laboratory analysis. Trends in 
Food Science and Technology, 27(2), 109-119. https://doi.org/10.1016/j.tifs.2012.04.005

Sultan, S. A. M. (2007). A Mini Guide to Shari'ah Audit for Islamic Financial InstitutionsA Primer. CERT Publications Sdn Bhd.

Sulub, S. A., Salleh, Z., \& Hashim, H. A. (2020). Corporate governance, SSB strength and the use of internal audit function by Islamic banks: Evidence from Sudan. Journal of Islamic Accounting and Business Research, 11(1), 152-167. https://doi.org/10.1108/JIABR-12-2016-0148

Tooranloo, H. S., \& Azizi, P. (2018). An analysis of causal relationships of ethical values in auditing from Islam's perspective: Using fuzzy DEMATEL approach. International Journal of Ethics and Systems, 34(3), 393-422. https://doi.org/10.1108/IJOES-02-2018-0035

Yaacob, H., \& Donglah, N. K. (2012). Shari'ah Audit in Islamic Financial Institutions: The Postgraduates' Perspective. International Journal of Economics and Finance, 4(12). https://doi.org/10.5539/ijef.v4n12p224

Zartha Sossa, J. W., Halal, W., \& Hernandez Zarta, R. (2019). Delphi method: analysis of rounds, stakeholder and statistical indicators. Foresight, 21(5), 525-544. https://doi.org/10.1108/FS-11-2018-0095 